\title{
Pathogenicity and Genetic Diversity of Fusarium oxysporum Causing Soybean Root Rot in Northeast China
}

\author{
Yonggang $\mathrm{Li}^{1,2}$, Tongxue Zhao ${ }^{1}$, Gia Khuong Hoang $\mathrm{Hua}^{2}$, Lankun $\mathrm{Xu}^{1}$, Jinxin $\mathrm{Liu}^{1}$, Shuxian $\mathrm{Li}^{3}$, Hanwen Huang ${ }^{4}$ \\ \& Pingsheng $\mathrm{Ji}^{2}$ \\ ${ }^{1}$ Agricultural College, Northeast Agricultural University, China \\ ${ }^{2}$ Department of Plant Pathology, University of Georgia, Tifton, GA, USA \\ ${ }^{3}$ USDA, Agricultural Research Service, Crop Genetics Research Unit, Stoneville, MS, USA \\ ${ }^{4}$ Department of Epidemiology and Biostatistics, University of Georgia, Athens, GA, USA \\ Correspondence: Yonggang Li, Key Laboratory of Cold Crop Breeding Improvement and Physiological Ecology \\ in Heilongjiang Province, Agricultural College, Northeast Agricultural University, Harbin 150030, China. Tel: \\ 086-0451-55191064. E-mail: neaulyg@126.com
}

Received: January 28, 2018

Accepted: March 11, $2018 \quad$ Online Published: April 15, 2018

doi:10.5539/jas.v10n5p13

URL: https://doi.org/10.5539/jas.v10n5p13

\begin{abstract}
Soybean is an important edible legume cultivated around the world. However, soybean production is seriously impacted by the widespread of root rot disease. In this study, genetic diversity and pathogenicity of Fusarium oxysporum associated with root rot of soybean in Heilongjiang province, China, were examined. A total of $50 \mathrm{~F}$. oxysporum strains were isolated from diseased soybean plants grown in Harbin, Heihe, Jixi, Jiamusi and Qiqihar of Heilongjiang province. Pathogenicity study indicated that all $F$. oxysporum strains were able to induce root rot disease on soybean in which $28 \%$ of the isolates were highly aggressive, $42 \%$ were moderately aggressive, and $30 \%$ were weakly aggressive. Aggressiveness of the isolates did not appear to be associated with geographic location or plant age of isolation. Genomic DNA of the isolates was analyzed by polymerase chain reaction using eight amplified fragment length polymorphism (AFLP) primers that generated 1728 bands, of which $99 \%$ were polymorphic. Cluster analysis using UPGMA showed that the similarity values ranged from 0.15 to 0.47 . At a similarity coefficient of 0.2 , the isolates were separated into 7 groups. Analysis of molecular variance indicated that about $92 \%$ of the genetic variation resided within populations. No correlation was found between genetic diversity and aggressiveness or the geographic origin of the isolates. Results of the study indicate that pathogenic F. oxysporum are commonly associated with root rot of soybean with various aggressiveness and they are genetically diverse.
\end{abstract}

Keywords: AFLP, soil borne pathogen, virulence, correlation

\section{Introduction}

Soybean [Glycine $\max$ (L.) Merr.] is an important oilseed crop and a valuable source of vegetable proteins (Loganathan et al., 2010). Approximately 7 million tons of soybean seeds were produced in 69 countries in the world (FAO, 2016). With the production of 693 thousand tons of soybean seeds, China is considered as one of the world's leading soybean producers (FAO, 2016). Total areas planted to soybean in China have been increasing, and the largest soybean producing province in the country is Heilongiiang (Li et al., 2013; Shurtleff \& Aoyagi, 2016). Heilongjiang is located in northeast China with 4.3 million hectares of soybean produced in the province (Shurtleff \& Aoyagi, 2016).

Soybean production is hampered by the occurrence of root rot disease caused by Fusarium spp. Fusarium root rot has been a problem in soybean production in many countries worldwide (Sinclair \& Backmen, 1989; Arias et al., 2013; Zhang et al., 2013a). Tap and lateral roots infected by the disease often become reddish brown or light to dark brown. The roots become shallow and fibrous and eventually rotted, and plants may be wilted especially under conditions of low moisture and high temperature. Root rot of soybean can be induced by various Fusarium species, with F. oxysporum being the most common species reported (Nelson, 1999; Shiraishi et al., 2012; Zhang et al., 2013a). 
Management of Fusarium root rot of soybean is difficult. Information regarding fungicides effective for suppressing $F$. oxysporum on soybean is limited. In northeast China, growers often abandon production of soybean when the fields get heavy infestation by the pathogen due to lack of effective disease control measures and panic of severe yield loss. Host resistance is a recommended strategy for managing soil borne diseases. In a study conducted in Canada (Zhang et al., 2013a), 70 soybean cultivars were evaluated under field conditions and 17 cultivars with the lowest severity of root rot caused by F. oxysporum, ranging from 1.3 to 2.2, were the most resistant. Soybean cultivars with resistance to Fusarium root rot under conditions in northeast China are not known to be available. It is unknown neither if F. oxysporum causing root rot of soybean are phenotypically and genetically diverse. It is highly desirable to determine diversity of the pathogen for developing effective disease management programs such as the use of host resistance.

Genomic fingerprinting techniques have been widely used to study genetic variability, population structure, and species phylogeny of $F$. oxysporum (Silva et al., 2013; Chen et al., 2014; Zimmermann et al., 2015). Among the techniques, amplified fragment length polymorphism (AFLP) is well recognized which has great discriminatory power (Vos et al., 1995; Mueller \& Wolfenbarger, 1999; Silva et al., 2013). In a study on Fusarium wilt of bitter gourd caused by F. oxysporum f. sp. momordicae, AFLP analysis differentiated isolates with high virulence from those with low virulence, and pathogenicity of the 48 pathogen isolates was correlated with geographical locations of isolation of the isolates (Chen et al., 2014). In another study on F. oxysporum f. sp. radicis-cucumerinum from cucumbers, analysis with AFLP markers divided the 30 isolates in two distinct clusters (Tok \& Kurt, 2010). All isolates in one cluster belonged to a vegetative compatibility group and isolates in the other cluster belonged to another vegetative compatibility group. These studies indicate that AFLP analysis is a useful tool in assessing genetic diversity of $F$. oxysporum populations.

The objective of this study was to determine pathogenicity of $F$. oxysporum associated with root rot of soybean in northeast China and use AFLP technology to analyze genetic diversity of the pathogen. This study advances our understanding of the etiology of the disease and population genetics of the pathogen, which provides valuable information for developing disease management programs.

\section{Materials and Methods}

\subsection{Sample Collection and Pathogen Identification}

Soybean plants showing root rot symptoms were sampled from different regions in Heilongjiang, China, in 2012 (Figure 1). Roots were washed with tap water, cut into pieces of $0.5 \mathrm{~cm}^{3}$, disinfested with $70 \%$ ethanol for $2 \mathrm{~s}$ and $0.5 \% \mathrm{NaOCl}$ for $5 \mathrm{~min}$, and rinsed three times with sterile distilled water. Root tissues were placed on potato dextrose agar (PDA) and incubated at $26^{\circ} \mathrm{C}$. Fungal hyphae grown from the tissues were transferred to fresh PDA plates. The isolates were identified as $F$. oxysporum according to cultural and morphological characteristics (Nelson et al., 1983; Leslie \& Summerell, 2006). Single conidium isolates were obtained using the methods reported previously (Leslie \& Summerell, 2006; Petkar et al., 2017).

For molecular identification, mycelia from 5-day-old cultures on PDA were used to extract DNA using the methods reported by Zhang et al. (2010) with minor modifications. In brief, mycelia of the isolates were pulverized using liquid nitrogen and homogenized using extraction buffer containing cetyl trimethyl ammonium bromide (CTAB), $0.5 \%$ charcoal along with $0.2 \% \beta$-mercaptoethanol. After incubation at $65{ }^{\circ} \mathrm{C}$ for 15 min, homogenates were purified three times with chloroform:isoamyl alcohol (24:1). The upper aqueous phase (400 $\mu \mathrm{L}$ ) was transferred to a tube containing $800 \mu \mathrm{L}$ isopropanol, and DNA pellets were obtained by adding 0.67 volumes of propanol. The pellets were washed with ice-cold ethanol $(70 \%)$, air dried, dissolved in $50 \mu \mathrm{L}$ of deionized water, and stored at $4{ }^{\circ} \mathrm{C}$. Polymerase chain reaction (PCR) analysis was performed with $F$. oxysporum species-specific primers FOF1 and FOR1 using the conditions described previously (Zhang et al., 2013b). PCR products were visualized by running $1.5 \%$ agarose gel and observed under a gel documentation system. 


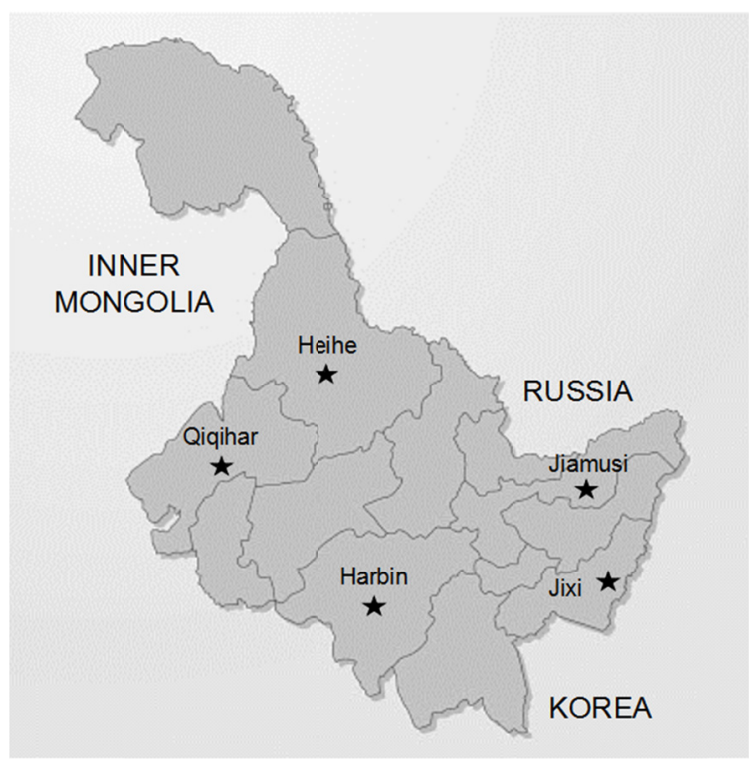

Figure 1. Map showing sampling locations of Fusarium oxysporum in Heilongiiang province, China

\subsection{Pathogenicity Tests}

To prepare inoculum of the isolates, flasks containing $125 \mathrm{~g}$ of sorghum seeds and $50 \mathrm{ml}$ of distilled water were autoclaved at $121^{\circ} \mathrm{C}$ for $40 \mathrm{~min}$ in two consecutive days. A mycelial plug (7 mm diameter) taken from 7-day-old cultures of the isolates was transferred to each flask. The flasks were incubated at $26^{\circ} \mathrm{C}$ for a week and mixed by hand every 3 days. Ten sorghum seeds fully colonized by $F$. oxysporum were uniformly distributed on the top of vermiculite in a plastic pot $(8 \times 8 \mathrm{~cm})$, and then covered with a $0.5 \mathrm{~cm}$ layer of sterile vermiculite. In the non-inoculated control, equal numbers of sterilized sorghum seeds were used. Twelve soybean seeds (cv. Hefeng 25) were surface-disinfested with $1.5 \% \mathrm{NaOCl}$ for $5 \mathrm{~min}$, washed three times with sterile distilled water, and sown in each pot. A randomized complete block design was used with three replicates and two pots for each isolate in each replicate. The pots were kept in a greenhouse at $25 \pm 3{ }^{\circ} \mathrm{C}$, and seedlings in each pot were thinned to 10 after emergence. The seedlings were watered daily using overhead irrigation to maintain soil moisture.

To evaluate disease severity, seedlings were removed from the pots 10 days after emergence and roots were washed under running tap water. Disease was rated using a 0-to-7 scale previously described by Li et al. (2013) where $0=$ healthy plant; $1=$ slightly darkening fibrous root, the aboveground portion grew well; $3=$ slightly darkening taproot, the aboveground portion grew well; $5=$ severe darkening taproot or hypocotyls erosion, the aboveground portion grew poorly; and $7=$ root necrotized and infected plant dead. The experiment was conducted twice under similar conditions. Disease data were expressed as Percent Disease Index (PDI) (Wheeler, 1969 ). Isolates were defined as highly aggressive if PDI $\geq 50 \%$, median aggressiveness if $50 \%>\mathrm{PDI} \geq 25 \%$, and low aggressiveness with PDI $<25 \%$. Diseased plants were sampled for isolation and identification of the causal agent as described above.

\subsection{Genetic Diversity of F. oxysporum Isolates}

Genomic DNA of 50 isolates was extracted as described above. Molecular fingerprinting of the isolates was conducted using AFLP markers with EcoRI and MesI as digestion enzymes. Adapters and primers used for AFLP analysis were designed as reported by Vuylsteke et al. (2007) and are listed in Table 1. 
Table 1. Sequences of adapters and primers used for AFLP analysis

\begin{tabular}{|c|c|c|c|}
\hline Restriction enzyme & Type & Code & Sequence \\
\hline \multirow[t]{11}{*}{ EcoRI } & Adapter & E1 & 5'-CTCGTAGACTGCGTACC-3' \\
\hline & & $\mathrm{E} 2$ & 5'-AATTGGTACGCAGTCTAC-3' \\
\hline & Primers & E00 & 5'-GACTGCGTACCAATTCA-3' \\
\hline & & E11 & 5'-GACTGCGTACCAATTCAAC-3' \\
\hline & & E12 & 5'-GACTGCGTACCAATTCAAG-3' \\
\hline & & E13 & 5'-GACTGCGTACCAATTCACA-3' \\
\hline & & E14 & 5'-GACTGCGTACCAATTCACT-3' \\
\hline & & E15 & 5'-GACTGCGTACCAATTCACC-3' \\
\hline & & E16 & 5'-GACTGCGTACCAATTCACG-3' \\
\hline & & E17 & 5'-GACTGCGTACCAATTCAGC-3' \\
\hline & & E18 & 5'-GACTGCGTACCAATTCAGG-3' \\
\hline \multirow[t]{11}{*}{ MseI } & Adapter & M1 & '5'-GACGATGAGTCCTGAG-3' \\
\hline & & M2 & 5'-TACTCAGGACTCAT-3' \\
\hline & Primers & M00 & 5'-GATGAGTCCTGAGTAAC-3' \\
\hline & & M11 & 5'-GATGAGTCCTGAGTAACAA-3' \\
\hline & & M12 & 5'- GATGAGTCCTGAGTAACAC-3' \\
\hline & & M13 & 5'-GATGAGTCCTGAGTAACAG-3' \\
\hline & & M14 & 5'-GATGAGTCCTGAGTAACAT-3' \\
\hline & & M15 & 5'- GATGAGTCCTGAGTAACTA-3' \\
\hline & & M16 & 5'-GATGAGTCCTGAGTAACTC-3' \\
\hline & & M17 & 5'-GATGAGTCCTGAGTAACTG-3' \\
\hline & & M18 & 5'-GATGAGTCCTGAGTAACTT-3' \\
\hline
\end{tabular}

\subsubsection{Modification of DNA and Template Preparation}

AFLP analysis was conducted using the methods of Vos et al. (1995) with minor modifications. To prepare DNA templates, $3 \mu \mathrm{L}$ genomic DNA $(150 \mathrm{ng} / \mu \mathrm{L})$ was incubated for $4 \mathrm{~h}$ at $37^{\circ} \mathrm{C}$ with $17 \mu \mathrm{L}$ of restriction digestion mixture containing $3 \mathrm{U}$ EcoRI $(15 \mathrm{U} / \mu \mathrm{L}), 3 \mathrm{U} \mathrm{MseI}(10 \mathrm{U} / \mu \mathrm{L}), 2.0 \mu \mathrm{L} 10 \times$ PCR buffer with BSA, and $14.5 \mu \mathrm{L}$ double-distilled water $\left(\mathrm{ddH}_{2} \mathrm{O}\right)$. Aliquots of $5 \mu \mathrm{L}$ digested DNA were then analyzed by electrophoresis in a $1.2 \%$ agarose gel. In the digestion process, digestion products were ligated with EcoRI and MseI adapters at the following conditions: $95^{\circ} \mathrm{C}$ for $5 \mathrm{~min}, 65^{\circ} \mathrm{C}$ for $10 \mathrm{~min}$, and $37^{\circ} \mathrm{C}$ for $10 \mathrm{~min}$.

\subsubsection{Ligation Reaction}

Before performing ligation reactions, restriction digestion mixture obtained from the previous step was incubated at $65{ }^{\circ} \mathrm{C}$ for $10 \mathrm{~min}$ to inactivate restriction enzymes. Each restricted DNA product was, then, incubated with 5 $\mu \mathrm{L}$ of ligation mixture, which consisted of $1.8 \mu \mathrm{L}$ ATP, $0.5 \mu \mathrm{L}$ EcoRI adapter mix, $1.0 \mu \mathrm{L}$ MseI adapter mix, 1.0 $\mu \mathrm{L}$ T4 DNA ligase, $0.5 \mu \mathrm{L} \mathrm{T} 4$ DNA ligase buffer, and $0.2 \mu \mathrm{LddH}_{2} \mathrm{O}$, at $37^{\circ} \mathrm{C}$ for $12 \mathrm{~h}$. A volume of $5 \mu \mathrm{L}$ ligated products was loaded on a $1.2 \%$ agarose gel to check for complete ligation. DNA templates, which were completely digested and ligated, were used for AFLP reactions.

\subsubsection{AFLP Reactions}

Pre-amplification was carried out in a volume of $20 \mu \mathrm{L}$ containing $5 \mu \mathrm{L}$ DNA template, $2.0 \mu \mathrm{L} 10 \times$ PCR buffer $\left(\mathrm{Mg}^{2+}\right), 1.6 \mu \mathrm{L}$ dNTPs $(2.5 \mathrm{mM}), 0.6 \mu \mathrm{L}$ primer E00 $(50 \mathrm{ng} / \mu \mathrm{L}), 0.6 \mu \mathrm{L}$ primer M00 $(50 \mathrm{ng} / \mu \mathrm{L}), 0.1 \mu \mathrm{L}$ Taq

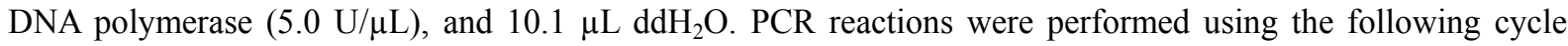
profile: $95{ }^{\circ} \mathrm{C}$ for $2 \mathrm{~min}, 30$ cycles of $95{ }^{\circ} \mathrm{C}$ for $30 \mathrm{~s}, 56^{\circ} \mathrm{C}$ for $30 \mathrm{~s}$, and $72{ }^{\circ} \mathrm{C}$ for $60 \mathrm{~s}$ followed by one cycle of $72{ }^{\circ} \mathrm{C}$ for $10 \mathrm{~min}$. Amplified products were stored at $4{ }^{\circ} \mathrm{C}$.

Prior to performing selective amplification, pre-selective PCR products were diluted 20 times using TE buffer. Twenty $\mu \mathrm{L}$ PCR reactions were conducted containing $5 \mu \mathrm{L}$ pre-amplified DNA, $2.0 \mu \mathrm{L} 10 \times$ PCR buffer $\left(\mathrm{Mg}^{2+}\right)$, $1.8 \mu \mathrm{L}$ dNTPs $(2.5 \mathrm{mM}), 0.8 \mu \mathrm{L}$ EcoRI primer $(50 \mathrm{ng} / \mu \mathrm{L}), 0.8 \mu \mathrm{L} \mathrm{MseI}$ primer $(50 \mathrm{ng} / \mu \mathrm{L}), 0.15 \mu \mathrm{L}$ Taq DNA

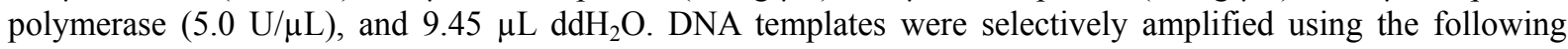
parameters: $95{ }^{\circ} \mathrm{C}$ for $50 \mathrm{~s}, 65^{\circ} \mathrm{C}$ for $40 \mathrm{~s}$ (with a gradually reduction of $0.7{ }^{\circ} \mathrm{C}$ per cycle), $72{ }^{\circ} \mathrm{C}$ for $1 \mathrm{~min}, 31$ 
cycles of $95{ }^{\circ} \mathrm{C}$ for $50 \mathrm{~s}, 56{ }^{\circ} \mathrm{C}$ for $40 \mathrm{~s}, 72{ }^{\circ} \mathrm{C}$ for $1 \mathrm{~min}$, and one cycle of $72{ }^{\circ} \mathrm{C}$ for 10 min before holding at $4{ }^{\circ} \mathrm{C}$. Finally, $5 \mu \mathrm{L}$ of PCR products was electrophoresed in a $2 \%$ agarose gel.

A total of 64 primer combinations were tested ( $8 \mathrm{EcoRI}$ primers and $8 \mathrm{Mse}$ primers) in this study and eight combinations, which generated clear bands with high polymorphism and good repeatability, were selected for genetic diversity analysis of the $50 \mathrm{~F}$. oxysporum isolates.

\subsection{Data Analysis}

Selective amplification products were visualized on 4\% polyacrylamide gels with an automatic DNA sequencer (ABI PRISM 377 sequencer; Promega, USA). Then, AFLP marker data (70-500 bp) were analyzed using GeneScan version 3.1 (Applied Biosystems, Foster City, CA, USA). The presence/absence of variable bands in the AFLP gel or autoradiogram was scored manually (' 1 ' for present and ' 0 ' for absent). Genetic distance was estimated and a dendrogram showing genetic relationship among the $F$. oxysporum isolates was constructed using NTSYSpc version 2.11V (Exeter Software, Setauket, NY) (Rohlf, 2004) based on unweighted pair-group method with arithmetic mean (UPGMA) clustering analysis (Kafkas et al., 2008). Analysis of molecular variance (AMOVA) was conducted using GenAlEx version 6.5 (Peakall \& Smouse, 2012).

\section{Results}

\subsection{Pathogenicity of Isolates}

Fifty $F$. oxysporum isolates were collected from five different geographic areas of Heilongjiang province, China, including 10 from Harbin, 7 from Heihe, 5 from Jixi, 11 from Jiamusi, and 17 from Qiqihar. The majority of $F$. oxysporum isolates $(68 \%)$ were obtained from soybean seedlings and the rest of the isolates were from mature soybeans (Table 2). When tested on soybean seedlings, significant variation in aggressiveness was observed among the isolates (Table 2). There were 15 weak pathogenic isolates (PDI $<25 \%$ ), 21 medium aggressive isolates $(25 \% \leq \mathrm{PDI}<50 \%)$, and 14 highly aggressive isolates (PDI $\geq 50 \%)$. The most aggressive isolate was $103(\mathrm{PDI}=82.9 \%)$ obtained from soybean seedling in Heihe. Isolates 12, 93, 33, 147, 163, 167, 125, 90, 91, 166, 150, 137 and 144 had disease index lower than 10\%. There was no correlation between aggressiveness of the isolates and their geographic origins, or between aggressiveness of the isolates and plant age (seedling or mature plant) when the fungus was isolated. 
Table 2. Pathogenicity of Fusarium oxysporum isolates on soybean under greenhouse conditions

\begin{tabular}{|c|c|c|c|c|}
\hline AFLP group & Strains & Origin & Sampling stage & DI $(\%)^{*}$ \\
\hline \multirow[t]{7}{*}{$\mathrm{E}$} & 11 & Qiqihar & Seedling & $62.4 \mathrm{H}$ \\
\hline & 16 & Qiqihar & Seedling & $62.9 \mathrm{H}$ \\
\hline & 14 & Qiqihar & Seedling & $42.9 \mathrm{M}$ \\
\hline & 15 & Qiqihar & Seedling & $45.2 \mathrm{M}$ \\
\hline & 19 & Qiqihar & Seedling & $40.5 \mathrm{M}$ \\
\hline & 30 & Heihe & Seedling & $71.4 \mathrm{H}$ \\
\hline & 36 & Heihe & Adult & $68.6 \mathrm{H}$ \\
\hline \multirow[t]{4}{*}{$\mathrm{F}$} & 12 & Qiqihar & Seedling & $5.7 \mathrm{~L}$ \\
\hline & 73 & Qiqihar & Adult & $46.7 \mathrm{M}$ \\
\hline & 79 & Harbin & Adult & $39.0 \mathrm{M}$ \\
\hline & 93 & Harbin & Adult & $2.4 \mathrm{~L}$ \\
\hline \multirow[t]{21}{*}{ A } & 9 & Qiqihar & Seedling & $42.4 \mathrm{M}$ \\
\hline & 33 & Heihe & Adult & $6.7 \mathrm{~L}$ \\
\hline & 103 & Heihe & Seedling & $82.9 \mathrm{H}$ \\
\hline & 84 & Qiqihar & Adult & $51.4 \mathrm{H}$ \\
\hline & 88 & Qiqihar & Seedling & $45.7 \mathrm{M}$ \\
\hline & 65 & Jixi & Seedling & $32.9 \mathrm{M}$ \\
\hline & 60 & Jixi & Seedling & $52.9 \mathrm{H}$ \\
\hline & 130 & Jiamusi & Seedling & $44.3 \mathrm{H}$ \\
\hline & 156 & Qiqihar & Seedling & $71.4 \mathrm{H}$ \\
\hline & 147 & Jiamusi & Seedling & $4.3 \mathrm{~L}$ \\
\hline & 49 & Jixi & Seedling & $37.1 \mathrm{M}$ \\
\hline & 161 & Harbin & Adult & $36.7 \mathrm{M}$ \\
\hline & 162 & Harbin & Adult & $16.7 \mathrm{~L}$ \\
\hline & 163 & Harbin & Adult & $9.5 \mathrm{~L}$ \\
\hline & 165 & Harbin & Adult & $42.9 \mathrm{M}$ \\
\hline & 167 & Qiqihar & Seedling & $6.2 \mathrm{~L}$ \\
\hline & 99 & Heihe & Seedling & $71.4 \mathrm{H}$ \\
\hline & 102 & Heihe & Adult & $64.8 \mathrm{H}$ \\
\hline & 122 & Jiamusi & Adult & $49.5 \mathrm{M}$ \\
\hline & 125 & Jiamusi & Seedling & $2.4 \mathrm{~L}$ \\
\hline & 119 & Jiamusi & Seedling & $37.6 \mathrm{M}$ \\
\hline \multirow[t]{5}{*}{ B } & 10 & Qiqihar & Seedling & $38.1 \mathrm{M}$ \\
\hline & 90 & Qiqihar & Seedling & $2.9 \mathrm{~L}$ \\
\hline & 91 & Qiqihar & Seedling & $3.8 \mathrm{~L}$ \\
\hline & 46 & Heihe & Adult & $33.8 \mathrm{M}$ \\
\hline & 76 & Harbin & Adult & $41.9 \mathrm{M}$ \\
\hline \multirow[t]{4}{*}{$\mathrm{C}$} & 158 & Qiqihar & Seedling & $29.5 \mathrm{M}$ \\
\hline & 159 & Qiqihar & Seedling & $55.2 \mathrm{H}$ \\
\hline & 166 & Harbin & Adult & $7.6 \mathrm{~L}$ \\
\hline & 164 & Harbin & Adult & $27.6 \mathrm{M}$ \\
\hline \multirow[t]{7}{*}{$\mathrm{D}$} & 135 & Jiamusi & Seedling & $50.0 \mathrm{H}$ \\
\hline & 149 & Jiamusi & Seedling & $16.2 \mathrm{~L}$ \\
\hline & 150 & Jiamusi & Seedling & $2.4 \mathrm{~L}$ \\
\hline & 140 & Jiamusi & Seedling & $44.3 \mathrm{M}$ \\
\hline & 146 & Jiamusi & Seedling & $33.3 \mathrm{M}$ \\
\hline & 152 & Harbin & Seedling & $51.4 \mathrm{H}$ \\
\hline & 145 & Jiamusi & Seedling & $42.9 \mathrm{M}$ \\
\hline \multirow[t]{2}{*}{ G } & 137 & Jixi & Seedling & $4.8 \mathrm{~L}$ \\
\hline & 144 & Jixi & Seedling & $4.8 \mathrm{~L}$ \\
\hline
\end{tabular}

Note. $* \mathrm{DI}=$ Disease index. $\mathrm{H}=$ highly aggressive with $\mathrm{DI} \geq 50 \% ; \mathrm{M}=$ Median aggressiveness with $25 \% \leq \mathrm{DI}<$ $50 \%$; and $\mathrm{L}=$ low aggressiveness with $\mathrm{DI}<25 \%$. 


\subsection{AFLP Analysis}

Eight primer pairs and their combinations were used to amplify $50 \mathrm{~F}$. oxysporum isolates and resulted in $99 \%$ polymorphic fragments. Totally, 216 different amplification products with fragment sizes ranging from 70 to 500 bp were produced. The highest number of polymorphic bands was generated with an AFLP primer combination E13/M13, whereas the lowest number of polymorphic bands was generated with primer combinations E11/M11, E15/M15 and E17/M13 (data not shown).

Cluster analysis showed that similarity values ranged from 0.15 to 0.47 (Figure 2). The highest similarity coefficient was measured between isolates 90 and 91 from Qiqihar. At a genetic similarity of 0.20 , the 50 isolates could be divided into seven groups. Group A contained 21 isolates from adult and young soybean seedlings with diverse origins including Harbin, Heihe, Jixi, Jiamusi, and Qiqihar. Group B contained 5 isolates, 3 from young seedlings in Qiqihar and 2 from adult plants in Heihe and Harbin. Group C contained 4 isolates from young and adult plants in Qiqihar and Harbin. Group D contained 7 isolates from young seedlings in Jiamusi and Harbin. Group E contained 7 isolates, all from young seedlings except one from an adult plant in Heihe. Group F contained 4 isolates from young and adult plants in Qiqihar and Harbin. Group G contained 2 isolates from young seedlings in Jixi.

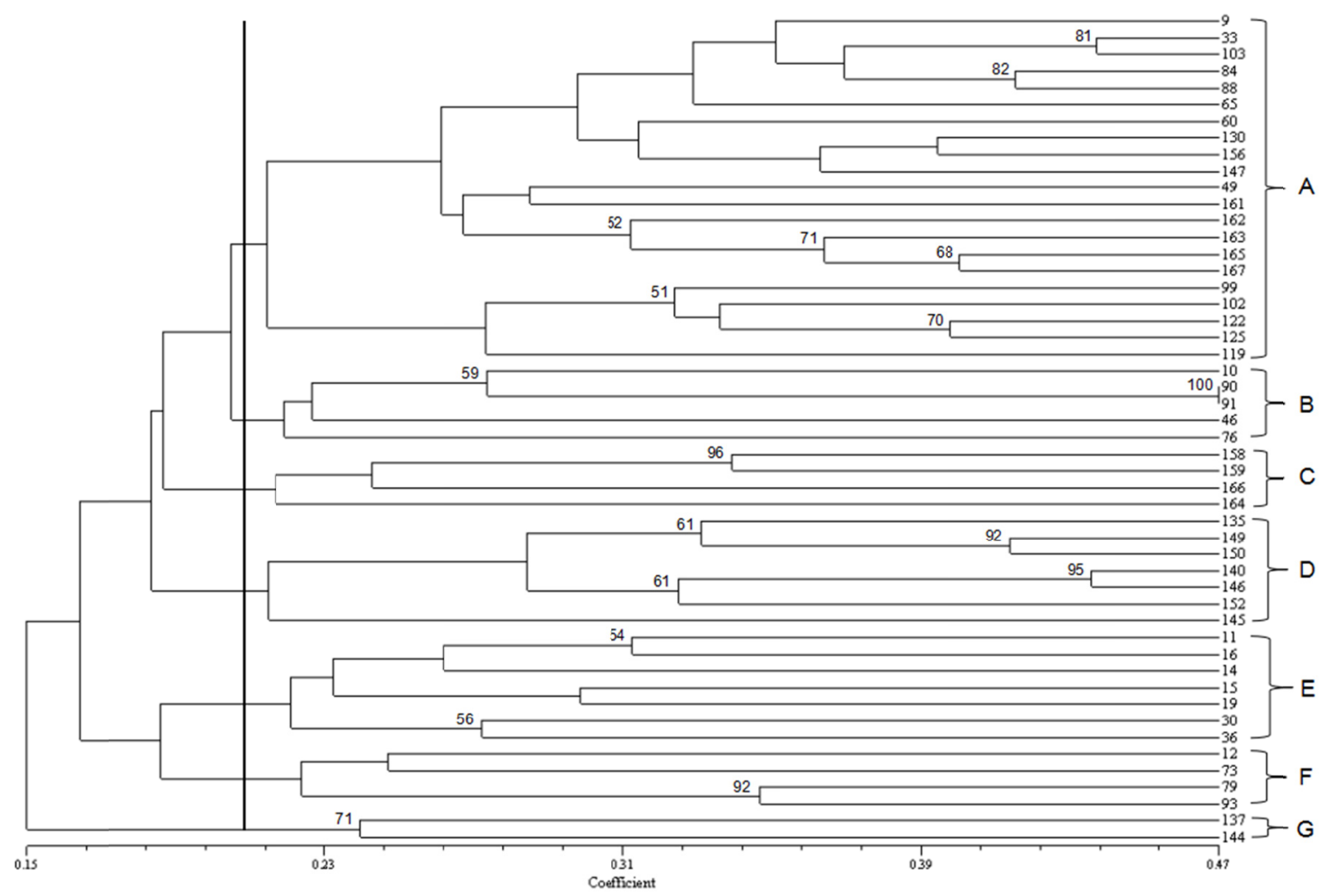

Figure 2. UPGMA tree of 50 Fusarium oxysporum isolates sampled from different soybean producing areas of Heilongjiang, China. Bootstrap values $\geq 50 \%$ are shown above branch

Highly significant $(P \leq 0.01)$ genetic differences were detected when AMOVA analysis was performed to estimate within-group and among-group variations according to AFLP genetic groups or geographic origins of the isolates (Table 3). The fixation index $\left(F_{S T}\right)$ is used to estimate the degree of population differentiation. It is suggested that $F_{S T}$ values from 0 to 0.05 represent little genetic differentiation, from 0.05 to 0.15 represent moderate genetic differentiation, from 0.15 to 0.25 represent great genetic differentiation, and $F_{S T}$ larger than 0.25 represent very great genetic differentiation (Hartl \& Clark, 1997). There was little genetic differentiation associated with geographic location of isolation, plant age of isolation, and aggressiveness of the isolates with $F_{S T}$ values lower than 0.05 . There was moderate genetic differentiation associated with AFLP groups. 
Table 3. Hierarchical partitioning of variance among and within population groups of Fusarium oxysporum strains based on analysis of molecular variance (AMOVA)

\begin{tabular}{|c|c|c|c|c|c|}
\hline Source of Variation & $\mathrm{df}$ & Variance & Total (\%) & $F_{S T}$ & $P$ \\
\hline \multicolumn{6}{|l|}{ Location } \\
\hline Among groups & 4 & 3.73 & 2.3 & 0.023 & 0.005 \\
\hline Within groups & 45 & 158.01 & 97.7 & & \\
\hline \multicolumn{6}{|l|}{ Plant age } \\
\hline Among groups & 1 & 0.16 & 0.1 & 0.001 & 0.362 \\
\hline Within groups & 48 & 160.82 & 99.9 & & \\
\hline \multicolumn{6}{|l|}{ Genetic group } \\
\hline Among groups & 6 & 13.01 & 7.94 & 0.079 & 0.001 \\
\hline Within groups & 43 & 150.83 & 92.06 & & \\
\hline \multicolumn{6}{|l|}{ Disease } \\
\hline Among groups & 2 & 0.37 & 0.23 & 0.0023 & 0.234 \\
\hline Within groups & 47 & 160.76 & 99.77 & & \\
\hline
\end{tabular}

\section{Discussion}

Fusarium species are common soil borne pathogens that cause destructive diseases on a wide range of hosts (Nelson et al., 1997; El-Kazzaz et al., 2008). F. oxysporum is frequently isolated from soybean roots and serious yield impact of root rot associated with Fusarium spp. is reported in many soybean producing areas (Wrather et al., 2001; Li \& Ma, 2011; Arias et al., 2013). In the present work, F. oxysporum was isolated from all the sampling sites in Heilongjiang province, suggesting that this pathogen is one of the most important causal agents of soybean root rot in this region. Our findings are in line with previous studies which showed F. oxysporum to be the predominant species recovered from diseased soybean plants in China (Bai et al., 2009; Li \& Ma, 2011) and other countries (Leslie et al., 1990; Nelson, 1999; Zhang et al., 2013a).

Variations in aggressiveness among pathogenic strains of $F$. oxysporum from soybean root were reported in a few studies. In a study to assess impact of Fusarium species on soybean yield and growth, significant difference was observed among the F. oxysporum strains in their ability to cause root rot and damping-off of soybean (Arias et al., 2013). Ellis et al. (2016) reported that 3 isolates of $F$. oxysporum caused high incidence of vascular discoloration of soybean stems or roots and 25 strains caused low to moderate levels of incidence, and one of the fungal effector genes, Six6, was found only in the strains causing high levels of vascular wilt. Of the 50 strains obtained from Heilongjiang province, 14 strains caused severe root rot, 21 strains were moderately aggressive and 15 strains induced low root rot severity on soybean, indicating significant variations in aggressiveness among the strains.

Studies to assess genetic diversity of $F$. oxysporum from soybean root are limited. In studies on $F$. oxysporum from other crops analyzed by AFLP, genetic groups were found to be associated with aggressiveness of $F$. oxysporum f. sp. momordicae isolates (Chen et al., 2014) or vegetative compatibility group of $F$. oxysporum $\mathrm{f}$. sp. radicis-cucumerinum isolates (Tok \& Kurt, 2010). AFLP was used in this study to access genetic diversity of $F$. oxysporum isolates in major soybean producing regions in Heilongiang. The eight primer pairs used resulted in 99\% polymorphic fragments, which is in agreement with previous reports that AFLP generates more polymorphic bands than other DNA-fingerprinting techniques (Vaneechoutte, 1996; Duan et al., 2008). AFLP analysis demonstrated great variability in genetic relatedness among the $50 \mathrm{~F}$. oxysporum strains from soybean, with 7 genetic groups identified at a similarity level of 0.2. AMOVA analysis indicated that most of molecular variation was attributed to within populations, suggesting high level of genetic variation and complexity of the $F$. oxysporum isolates. AFLP groups were not correlated with geographic location of isolation, plant age of isolation, or aggressiveness of the isolates, as suggested by low $F_{S T}$ values $(<0.03)$.

In a study of Fusarium oxysporum $\mathrm{f}$. sp. lentis isolates from lentil plants, the isolates were clustered in two AFLP groups, and no correlation was found between AFLP grouping and geographical origin or aggressiveness of the isolates (Belabid et al., 2004). AFLP analysis was conducted to study mutation of $F$. oxysporum $\mathrm{f}$. sp. vasinfectum isolates associated with cotton, and there was no correlation between the AFLP mutations and increased aggressiveness of the isolates (Wang et al., 2008). Duan et al. (2008) reported that AFLP groups of F. oxysporum $\mathrm{f}$. sp. niveum isolates were not associated with geographic regions of the isolates but were correlated with their 
physiological races. These studies indicate that AFLP grouping may or may not be related to phenotypic traits of F. oxysporum isolates, depending on the pathogens and host plants studied.

\section{Conclusion}

Soybean root rot is a serious disease causing significant yield reduction in soybean production. Results in the study indicate that there is a high level of genetic diversity within $F$. oxysporum strains responsible for soybean root rot in Heilongjiang province, China. The strains differ in aggressiveness that is not associated with their geographic distribution, plant age of isolation, and molecular fingerprinting groups. The information generated in the study advances our knowledge about etiology, pathogenicity, and diversity of soybean root rot pathogen, which facilitates development of effective strategies for managing this major disease.

\section{Acknowledgements}

This research was funded by China National "13th Five-Year" Science and Technology Innovation for Improving Food Production and Efficiency Project (2016YFD0300704).

Mention of trade names or commercial products in this publication is solely for the purpose of providing specific information and does not imply recommendation or endorsement by the U.S. Department of Agriculture. USDA is an equal opportunity provider and employer.

\section{References}

Arias, M. M. D., Leandro, L. F., \& Munkvold, G. P. (2013). Aggressiveness of Fusarium species and impact of root infection on growth and yield of soybeans. Phytopathology, 103, 822-832. https://doi.org/10.1094/ PHYTO-08-12-0207-R

Bai, L. Y., Zhang, Q. D., Li, B., \& Guo, Q. Y. (2009). Identification and pathogenicity determination of the pathogenic Fusarium of soybean root rot in the Altay region of Xinjiang. Xinjiang Agricultural Science, 46, 543-548.

Belabid, L., Baum, M., Fortas, Z., Bouznad, Z., \& Eujayl, I. (2004). Pathogenic and genetic characterization of Algerian isolates of Fusarium oxysporum f. sp. lentis by RAPD and AFLP analysis. African Journal of Biotechnology, 3(1), 25-31. https://doi.org/10.5897/AJB2004.000-2005

Chen, Z. D., Huang, R. K., Li, Q. Q., Wen, J. L., \& Yuan, G. Q. (2014). Development of pathogenicity and AFLP to characterize Fusarium oxysporum f. sp. momordicae isolates from bitter gourd in China. Journal of Phytopathology, 163, 202-211. https://doi.org/10.1111/jph.12310

Duan, H. J., Zhang, C. Y., Li, X. H., Guo, X. M., \& Ma, Z. Y. (2008). Assessment of genetic diversity in Fusarium oxysporum f. sp. niveum by RAPD, ISSR and AFLP analysis. Mycosystema, 27(2), 267-276.

El-Kazzaz, M. K., El-Fadly, G. B., Hassan, M. A. A., \& El-Kot, G. A. N. (2008). Identification of some Fusarium spp. using molecular biology techniques. Egyptian Journal of Phytopathology, 36, 57-69.

Ellis, M. L., Lanubile, A., Garcia, C., \& Munkvold, G. P. (2016). Association of putative fungal effectors in Fusarium oxysporum with wilt symptoms in soybean. Phytopathology, 106, 762-773. https://doi.org/ 10.1094/PHYTO-11-15-0293-R

FAO. (2016). Retrieved May 3, 2016, from http://faostat.fao.org/site/567/DesktopDefault.aspx\#ancor

Hartl, D. L., \& Clark, A. G. (1997) Principles of population genetics (3rd ed.). Sinauer Associates, Inc., Sunderland, MA, USA.

Kafkas, S., Özgen, M., Doǵan, Y., Özcan, B., Ercisxli, S., \& Sercxe, S. (2008). Molecular characterization of mulberry accessions in Turkey by AFLP markers. Journal of the American Society for Horticultural Science, 133, 593-597. Retrieved from https://www.researchgate.net/publication/228757163

Leslie, J. F., \& Summerell, B. A. (2006). The Fusarium laboratory manual. Blackwell Publishing, Victoria, Australia. https://doi.org/10.1002/9780470278376

Leslie, J. F., Pearson, C. A. S., Nelson, P. E., \& Toussoun, T. A. (1990). Fusarium spp. from corn, sorghum, and soybean fields in the central and eastern United States. Phytopathology, 80, 343-350. https://doi.org/10.1094/Phyto-80-343

Li, Y. G., \& Ma, F. M. (2011). Antagonistic mechanism of Fusarium oxysporum of soybean root rot by Bacillus subtilis. Applied Mechanics and Materials, 108, 127-131. https://doi.org/10.4028/www.scientific.net/AMM. 108.127 
Li, Y. G., Zhang, L., Wang, C. L., Geng, X. B., \& Li, W. B. (2013). Antagonistic mechanism and control effect of Bacillus subtilis Y2 against Fusarium oxysporum causing soybean root rot. African Journal of Microbiology Research, 7(8), 652-656. https://doi.org/10.5897/AJMR12.1555

Loganathan, M., Maruthasalam, S., Shiu, L. Y., Lien, W. C., Hsu, W. H., Lee, P. F., ... Lin, C. H. (2010). Regeneration of soybean (Glycine max L. Merrill) through direct somatic embryogenesis from the immature embryonic shoot tip. In Vitro Cellular \& Developmental Biology-plant, 46(3), 265-273. https://doi.org/ $10.1007 / \mathrm{s} 11627-009-9263-1$

Mueller, U. G., \& Wolfenbarger, L. L. (1999). AFLP genotyping and fingerprinting. Trends in Ecology and Evolution, 14, 389-394. https://doi.org/10.1016/S0169-5347(99)01659-6

Nelson, B. D. (1999). Fusarium blight or wilt, root rot, and pod and collar rot. Compendium of Soybean Diseases (3rd ed., pp. 35-36). American Phytopathological Society, St. Paul, MN, USA.

Nelson, B. D., Hansen, J. M., Windels, C. E., \& Helms, T. C. (1997). Reaction of soybean cultivars to isolates of Fusarium solani from Red river valley. Plant Disease, 81, 664-668. http://dx.doi.org/10.1094/PDIS.1997.81. 6.664

Nelson, P. E., Toussoun, T. A., \& Marasas, W. F. O. (1983). Fusarium species: An illustrated manual for identification. Pennsylvania State University Press, University Park, PA, USA.

Peakall, R., \& Smouse, P. E. (2012). GenAlEx 6.5: Genetic analysis in Excel. Population genetic software for teaching and research-an update. Bioinformatics, 28, 2537-2539. https://doi.org/10.1111/j.1471-8286.2005. 01155.x

Petkar, A., Langston, D. B., Buck, J. W., Stevenson, K. L., \& Ji, P. (2017). Sensitivity of Fusarium oxysporum f. sp. niveum to prothioconazole and thiophanate-methyl and gene mutation conferring resistance to thiophanate-methyl. Plant Disease, 101, 366-371. https://doi.org/10.1094/PDIS-09-16-1236-RE

Rohlf, F. J. (2004). NTSYS-pc: Numerical taxonomy and multivariate analysis system (Version 2.11V). Exeter Software, Setauket, New York.

Shiraishi, A., Leslie, J. F., Zhong, S. B., \& Uchida, J. Y. (2012). AFLP, pathogenicity, and VCG analyses of Fusarium oxysporum and Fusarium pseudocircinatum from Acacia koa. Plant Disease, 96, 1111-1117. https://doi.org/10.1094/PDIS-06-11-0491

Shurtleff, W., \& Aoyagi, A. (2016). History of modern soy protein ingredients-isolates, concentrates, and textured soy protein products (1911-2016): Extensively annotated bibliography and sourcebook. Soyinfo Center, 1669.

Silva, A. D. S., de Oliveira, E. J., Haddad, F., de Jesus, O. N., de Oliveira, S. A. S., \& de Carvalho Costa, M. A. P. (2013). Molecular fingerprinting of Fusarium oxysporum f. sp. passiflorae isolates using AFLP markers. Scientia Agricola, 70(2), 108-115. https://doi.org/10.1590/S0103-90162013000200008

Sinclair, J. B., \& Backmen, P. A. (1989). Compendium of soybean diseases (3rd ed.). The American Phytopathological Society, St. Paul., MN, USA.

Tok, F. M., \& Kurt, S. (2010). Pathogenicity, vegetative compatibility and amplified fragment length polymorphism (AFLP) analysis of Fusarium oxysporum f. sp. radicis-cucumerinum isolates from Turkish greenhouses. Phytoparasitica, 38(3), 253-260. https://doi.org/10.1007/s12600-010-0099-3

Vaneechoutte, M. (1996). DNA fingerprinting techniques for microorganisms. A proposal for classification and nomenclature. Molecular Biotechnology, 6, 115-142. https://doi.org/10.1007/BF02740768

Vos, P., Hogers, R., Bleeker, M., Reijans, M., van de Lee, T., Hornes, M., ... Kuiper, M. (1995). AFLP: A new technique for DNA fingerprinting. Nucleic Acids Research, 23, 4407-4414. https://doi.org/10.1093/nar/ 23.21.4407

Vuylsteke, M., Peleman, J. D., \& van Eijk, M. J. T. (2007). AFLP technology for DNA fingerprinting. Nature Protocols, 2, 1387-1398. https://doi.org/10.1038/nprot.2007.175

Wang, B., Brubaker, C. L., Tate, W., Woods, M. J., \& Burdon, J. J. (2008). Evolution of virulence in Fusarium oxysporum f. sp. vasinfectum using serial passage assays through susceptible cotton. Phytopathology, 98, 296-303. https://doi.org/10.1094/PHYTO-98-3-0296

Wheeler, B. E. J. (1969). An introduction to plant disease. Wiley, London. 
Wrather, J. A., Anderson, T. R., Arsyad, D. M., Tan, Y., Ploper, L. D., Porta-Puglia, A., ... Yorinori, J. T. (2001). Soybean disease loss estimates for the top ten soybean producing countries in 1998. Canadian Journal of Plant Pathology, 23, 115-121. https://doi.org/10.1080/07060660109506918

Zhang, J. X., Xue, A. G., Cober, E. R., Morrison, M. J., Zhang, H. J., Zhang, S. Z., \& Gregorich, E. (2013a). Prevalence, pathogenicity and cultivar resistance of Fusarium and Rhizoctonia species causing soybean root rot. Canadian Journal of Plant Science, 93(2), 221-236. https://doi.org/10.4141/CJPS2012-223

Zhang, S., Zhao, B., \& Liu, L. J. (2013b). DNA Sequencing and UP-PCR Characterization of Fusarium oxysporum Isolates from Three Cucurbit Species. The Plant Pathology Journal, 12(2), 78-84. https://doi.org/10.3923/ppj.2013.78.84

Zhang, Y. J., Zhang, S., Liu, X. Z., Wen, H. A., \& Wang, M. (2010). A simple method of genomic DNA extraction suitable for analysis of bulk fungal strains. Letters in Applied Microbiology, 51, 114-118. https://doi.org/10.1111/j.1472-765X.2010.02867.x

Zimmermann, J., de Klerk, M., Musyoki, M. K., Viljoen, A., Watson, A. K., Beed, F., ... Rasche, F. (2015). An explicit AFLP-based marker for monitoring Fusarium oxysporum f. sp. strigae in tropical soils. Biological Control, 89, 42-52. https://doi.org/10.1016/j.biocontrol.2015.02.008

\section{Copyrights}

Copyright for this article is retained by the author(s), with first publication rights granted to the journal.

This is an open-access article distributed under the terms and conditions of the Creative Commons Attribution license (http://creativecommons.org/licenses/by/4.0/). 